\title{
The diversity of diatom assemblages developed on fallow soil in Pogórska Wola near Tarnów (southern Poland)
}

\author{
Jadwiga Stanek-Tarkowska1* , Teresa Noga ${ }^{2}$, Natalia Kochman-Kędziora³, Łukasz Peszek³, Anita Pajączek4, \\ Edyta Kozak ${ }^{4}$ \\ 1 Department of Soil Studies, Environmental Chemistry and Hydrology, Faculty of Biology and Agriculture, University of Rzeszów, Zelwerowicza 8b, 35-601 Rzeszów, Poland \\ 2 Department of Biological Foundations of Agriculture and Environmental Education, Faculty of Biology and Agriculture, University of Rzeszów, Ćwiklińskiej 2, 35-601 Rzeszów, Poland \\ ${ }^{3}$ Department of Agroecology, Faculty of Biology and Agriculture, University of Rzeszów, Ćwiklińskiej 2, 35-601 Rzeszów, Poland \\ ${ }^{4}$ Department of Soil Studies, Environmental Chemistry and Hydrology, Faculty of Biology and Agriculture, University of Rzeszów, Zelwerowicza 8b, 35-601 Rzeszów, Poland
}

\begin{abstract}
The aim of this work was to investigate the species diversity of diatoms growing on fallow fields on loose sand. The study site was located in the western part of Pogórska Wola near Tarnów (southern Poland). Samples were collected from fallow land once a month from April to December 2011. 57 diatom taxa from 19 different genera were found. The most numerous genera were Fragilaria (8) and Luticola (7). The highest species richness was observed in December, November and July, while the highest values of species diversity (Shannon-Wiener index) were recorded between August and October. Four taxa - Pinnularia borealis Ehrenb. var. borealis, Stauroneis borrichii (Petersen) Lund, Hantzschia amphioxys (Ehrenb.) Grunow, and Luticola nivalis (Ehrenb.) D.G. Mann, were found to be the dominant species. Neutral species (a pH of about 7) dominated in all months (from April to December), reaching an over $90 \%$ share in the assemblage. In terms of nitrogen content, nitrogen-autotrophic taxa, tolerating an elevated concentration of organically bound nitrogen, occurred most abundantly, as was indicated by the low content of nitrogen in the soil.
\end{abstract}

Keywords: soil algae; loose sand; Bacillariophyceae; species diversity

\section{Introduction}

Over recent years, soil algae have been the object of many ecological, physiological and biochemical studies. They play a significant role in the colonization of low productive soils, which results from volcanic activity, retreating of glaciers, fires, or mining activity. The biomass of photoautotrophic soil algae is a source of humus and nitrogen. They produce organic matter and other organic compounds, e.g. amino acids, organic acids, polysaccharides and vitamins, which influence the life cycles of other soil organisms and vascular plants [1-3].

Edaphic ecosystems are characterized by instability of environmental conditions. The key factors that determine algal growth in soils are insolation, soil moisture, temperature, and water availability. Sunlight penetrates only a few millimeters into the soil and therefore soil algae are exposed to high sunlight as well as some deficits. They live in varying temperatures (from extremely high to extremely low), so they can colonize deserts in both tropical and Antarctic

* Corresponding author. Email: jagodastanek@wp.pl

Handling Editor: Elżbieta Weryszko-Chmielewska climates. Soil algae can fix some mineral components from the soil, thereby taking part in the process of soil stabilization. Thanks to durable valves, composed of silica, diatoms are an important part of fossil flora, where they occur in the form of diatomite (diatomaceous earth) [4-9].

An important factor affecting the species composition of algal communities is soil pH. Most algae (diatoms as well) prefer neutral or slightly alkaline soils [4-8].

Green and blue-green algae are among the most studied soil algae. Green algae occur in a wide range of $\mathrm{pH}$, while soil cyanobacteria dominate on neutral and slightly alkaline soils. Some species of edaphic algae, which are able to assimilate nitrogen, can colonize specific ecosystems, such as deserts. Diatoms are rarely identified in soil algae studied [10-20]. Although some research has been carried out on the ecology and species composition of soil diatoms [10,13,21-28], no studies have been found which concern soils developed on fallow land. Also, no research studies have been conducted on the diversity of soil diatom communities in the area of the Małopolska region (southern Poland). Only two studies have attempted to investigate diatom communities growing in cultivated fields in Dąbrowa and Boguchwała in the Podkarpacie region $[27,28]$. 
The aim of this study was to investigate the species diversity of diatoms growing on fallow fields situated on loose sands and to attempt to identify the factors that have a direct effect on the variation in diatom assemblages.

\section{Material and methods}

\section{Study area}

The study area is situated in Pogórska Wola, in the municipality of Skrzyszów located within two major morphological units: Pogórze Karpackie and Kotlina Sandomierska [29] (Fig. 1).

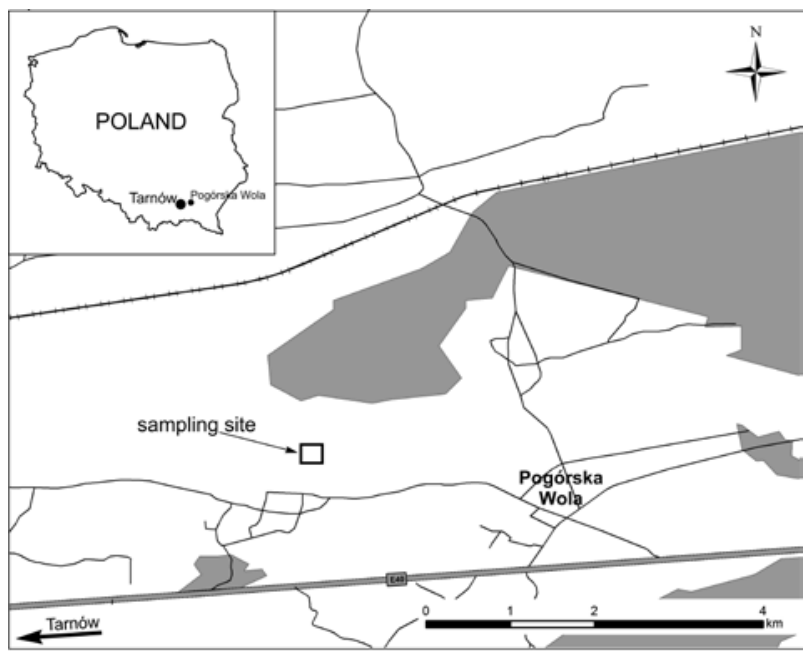

Fig. 1 Location of the sampling site in Pogórska Wola (grey color indicates forested areas).

The study sites were located in the western part of Pogórska Wola, on a small flat hill where the bedrock consists of loose sand. There is no watercourse near the study site, so the research area was never flooded. The field had been fallow for about eight years. Rye and triticale had been grown there previously. The land surrounding the study site is still farmed.

The climate in the study area is transitional (between oceanic and continental). The area near Tarnów is known as a "heat island", with the longest summer in Poland (about 114 days), so the growing season in the area lasts up to 225 days. The area around Tarnów receives $700 \mathrm{~mm}$ of rainfall per year (maximum rainfall is in July and minimum rainfall in February) [30]. The average total precipitation for the meteorological station in Tarnów was $600.7 \mathrm{~mm}$ in 2011 (data provided by the Organization Department for the Hydrological and Meteorological Services Center for Poland's Climate Monitoring Institute of Meteorology and Water Management National Research Institute IMGW-PIB Warsaw).

Materials for the study were collected from fallow land in the village of Pogórska Wola once a month between April and December 2011. Soil samples were collected from a $0-3 \mathrm{~cm}$ deep layer and placed in three Petri dishes, with a diameter of $8.8 \mathrm{~cm}$ (the average weight of fresh soil in the dish was about $90 \mathrm{~g})$. At the same time, samples were taken from the top soil layer $(0-5 \mathrm{~cm})$ and basic physico-chemical analysis was performed (moisture, $\mathrm{pH}$, organic matter and nitrogen content, granulometric composition). Additional soil samples were collected in Kopecki cylinders (in three replications) to examine soil moisture.

The analysis of soil moisture was carried out in a laboratory using the drying-weighing method. A small amount of soil material (about $10 \mathrm{~g}$ ) from the Petri dishes was placed in beakers with a capacity of $100 \mathrm{ml}$ and they were filled with a chromic acid cleaning mixture in order to obtain pure valves of diatoms. Then, the samples were cleaned by centrifugation. The diatoms were mounted on permanent diatom slides with synthetic resin - Pleurax. The material was prepared according to the methods applied by Kawecka [31], Stanek-Tarkowska and Noga [27,28].

Diatoms were identified using a Nikon ECLIPSE 80i light microscope, according to the following keys: Krammer and Lange-Bertalot [32-35], Ettl and Gärtner [18], Krammer [36], Hofmann et al. [37].

Pictures of diatoms were taken using an optical microscope (Nikon ECLIPSE 80i) and a scanning electron microscope (HITACHI S-4700) at the laboratory of field emission microscopy, scanning electron microscopy and microanalysis (Institute of Geological Sciences of the Jagiellonian University in Cracow).

The number of diatoms was obtained by counting all valves in randomly selected microscopic fields of view, up to a total of 400 valves. Species whose percentage in a given community was $5 \%$ or more were classified as dominant [27,28,31].

According to the red list of algae [38], diatom taxa were assigned to threat categories.

The assessment of ecological preferences of diatoms was performed using the list proposed by van Dam et al. [39]. The following indicators were taken into consideration: $\mathrm{pH}$, moisture and nitrogen uptake metabolism diatom type.

The following physico-chemical analyses of soil were performed: $\mathrm{pH}$ in $\mathrm{KCl}$, organic matter content was determined using Tiurin's method [40], granulometric composition was determined by the application of Bouyoucos-Casagrande's method, with Pruszyński's modifications (according to the Polish Standard PN-78/9180-11), nitrogen content using Kjeldahl method [41], and soil moisture - using the dryingweighing method.

The species diversity of diatom assemblages was determined by the Shannon-Wiener $\left(H^{\prime}\right)$ species diversity index:

$$
H^{\prime}=\sum_{i=1}^{s}\left(\frac{n_{i}}{n} \log _{2} \frac{n_{i}}{n}\right)
$$

$n_{i}$ - number of individual diatoms of the species $i$

$n$ - total number of individual counts $\left(n_{i} / n\right.$ - relative abundance of the species $i$ )

$s$ - total number of diatom taxa occurring in the sampling site.

A graph of moisture distribution in each month was made using STATISTICA software (version 10.0). 


\section{Results}

The soil in the study site in Pogórska Wola was characterized by an acidic reaction (4.1-5.3) and the lowest $\mathrm{pH}$ values were recorded in the summer months. The granulometric composition analysis showed that the studied soil can be classified as loose sand ( $65 \%$ of sand, $24 \%$ of silt, $1 \%$ of clay). The content of organic matter ranged from $1.37 \%$ in November to $2.04 \%$ in May 2011. The highest soil moisture occurred in the autumn and winter months, the lowest one in summer (Fig. 2). Physico-chemical examination showed a low level of soil nitrogen concentrations, similar in all months (Tab. 1).

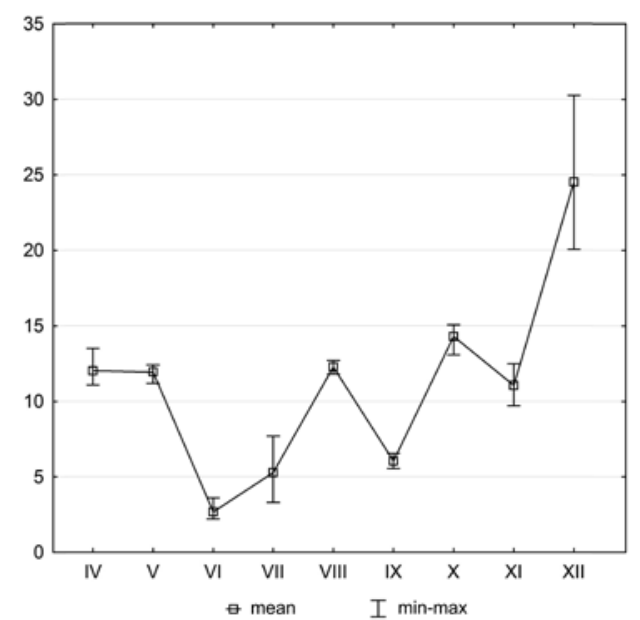

Fig. 2 Changes in soil moisture (\%) at the sampling site (IV-XII - months from April to December).

Tab. 1 The values of physico-chemical parameters in each month from April to December (IV-XII) in 2011.

\begin{tabular}{lccccccccc} 
Month & IV & V & VI & VII & VIII & IX & X & XI & XII \\
\hline Moisture (\%) & 12.01 & 11.90 & 2.60 & 5.20 & 12.25 & 6.04 & 14.30 & 11.05 & 24.72 \\
$\mathrm{pH}(\mathrm{KCl})$ & 5.3 & 5.0 & 4.4 & 4.1 & 4.1 & 4.8 & 5.1 & 4.2 & 4.2 \\
Organic matter (\%) & 1.63 & 2.04 & 1.81 & 1.47 & 1.42 & 1.76 & 1.42 & 1.37 & 1.55 \\
Nitrogen content (\%) & 0.08 & 0.05 & 0.07 & 0.06 & 0.07 & 0.08 & 0.08 & 0.06 & 0.07 \\
\hline
\end{tabular}

During the study, a total 57 diatom taxa from 19 different genera were found. The most numerous were species of the genera Fragilaria (8) and Luticola (7). The highest species richness was recorded in December, November and July, while the highest values of species diversity according to the Shannon-Wiener index were noted from August to October (Tab. 2).

Four taxa - Pinnularia borealis Ehrenberg var. borealis, Stauroneis borrichii (Petersen) Lund, Hantzschia amphioxys (Ehrenberg) Grunow, and Luticola nivalis (Ehrenberg) D.G. Mann), which were found in a proportion of more than 5\% in at least one sample, were considered to be the dominant species (Fig. 3, Fig. 4).
The largest populations were formed by Pinnularia borealis var. borealis; it always reached an over $20 \%$ share in the assemblage, while in April and July even more than $60 \%$. Hantzschia amphioxys (15-27.5\%) and Stauroneis borrichii also occurred numerously, reaching the highest percentage in August - 32\%, while Luticola nivalis were numerous only in autumn (Tab. 3).

Alkaliphilous taxa dominated (more than 90\%) in all samples. In respect of nitrogen uptake metabolism, nitrogenautotrophic diatom taxa, tolerating an elevated concentration of organically bound nitrogen, were most frequent. Diatoms growing mainly on wet or temporarily dry places were the most numerous in all months (Fig. 5-Fig. 7).

Among 57 diatom taxa identified, seven were on the Polish red list of algae [38]. Three taxa from the genus Pinnularia were in the endangered category (E): P. schoenfelderi Krammer, $P$. subrupestris Krammer and $P$. viridiformis Krammer, whereas two in the vulnerable category (V): Aulacoseira crenulata (Ehrenberg) Thwaites and Fragilaria tenera (W. Smith) Lange-Bertalot. Two taxa from the rare category (R) were also found: Luticola acidoclinata Lange-Bertalot and Stauroneis termicola (Petersen) Lund (Tab. 2).

\section{Discussion}

The organic matter content of the soil is one of the most important parameters, affected not only by the system of cultivation and fertilization, but also by high agricultural culture and the character of the bedrock. In the past, arable land was often left fallow in order to improve the physical and chemical conditions of the soil, whereas currently arable land is left fallow due to the unprofitability of agricultural production. The field on which the present study was conducted had been left fallow for about 8 years for economic reasons. During the study period, the organic matter content was variable - the highest value was recorded in May (2.04\%), while the lowest one was noted on November (1.37\%). Czyż et al. [42] indicated a correlation between organic matter content and the amount of water in the soil - the more organic matter, the greater amount of water in the soil. The present study did not confirm the above relationship, since the highest moisture occurred in the autumn and winter months (Tab. 1).

The highest rainfall was recorded in the second half of July $(181 \mathrm{~mm})$ and in June $(112.9 \mathrm{~mm})$, while in the remaining months of the growing season the rainfall was low and ranged from $21.4 \mathrm{~mm}$ in September to $61 \mathrm{~mm}$ in April (data provided by the Organization Department for the Hydrological and Meteorological Services Center for Poland's Climate Monitoring Institute of Meteorology and Water Management National Research Institute IMGW-PIB Warsaw). As regards the weather conditions that occurred in 2011, the dates of sampling coincided with the lack of rainfall and the present study showed a relatively high species richness of diatoms - 57 taxa were noted from 19 different genera. Two similar studies carried out in the neighboring region, but on cultivated soils, showed a similar species richness of diatoms - 47 diatom taxa were found at the study site in Boguchwała, whereas in Dąbrowa - 62 taxa [27,28]. On 
Tab. 2 The list of diatom taxa identified on fallow soil in Pogórska Wola near Tarnów and the categories of threats (according to Siemińska et al. [38]): E - endangered, V - vulnerable, R - rare. "+" means the taxon was found in a given study month. RL means the category of threat.

\begin{tabular}{|c|c|c|c|c|c|c|c|c|c|c|}
\hline \multirow[b]{2}{*}{ Taxa } & \multicolumn{9}{|c|}{2011} & \multirow[b]{2}{*}{$\mathbf{R L}$} \\
\hline & IV & $\mathbf{V}$ & VI & VII & VIII & IX & $\mathbf{X}$ & $\mathbf{X I}$ & XII & \\
\hline Achnanthidium pyrenaicum (Hustedt) Kobayasi & & + & & + & & + & & & & \\
\hline Amphora pediculus (Kützing) Grunow & & & & & & + & & & & \\
\hline Amphora sp. & + & & & & & & & & & \\
\hline Aulacoseira crenulata (Ehrenberg) Thwaites & & & & & & & & & + & $\mathrm{V}$ \\
\hline Aulacoseira distans (Ehrenberg) Simonsen & & & & + & + & + & + & & + & \\
\hline Aulacoseira granulata (Ehrenberg) Simonsen & & & + & + & + & + & + & + & & \\
\hline Aulacoseira cf. crenulata (Ehrenberg) Thwaites & & & & & + & & & + & & \\
\hline Cyclostephanos dubius (Hustedt) Round & & + & + & & + & & & + & + & \\
\hline Cyclotella maneghiniana Kützing & & & & + & + & & & & & \\
\hline Cymbella excisa Kützing & & & & + & & & & + & & \\
\hline Diadesmis sp. & & & & & & & & + & & \\
\hline Diatoma vulgaris Bory & & & & + & & & & + & & \\
\hline Encyonema reichardtii (Krammer) D.G. Mann & & & & & & + & & & & \\
\hline Encyonema silesiacum (Bleisch) D.G. Mann & & & & + & & & & & & \\
\hline Encyonema ventricosum (Agardh) Grunow & & + & & & & & & + & & \\
\hline Encyonema vulgare Krammer var. vulgare & & & & & & & & & + & \\
\hline Eolimna minima (Grunow) Lange-Bertalot & & & & + & & & & & & \\
\hline Eunotia curtagrunowii Nörpel-Schempp \& Lange-Bertalot & & & & & & + & & & & \\
\hline Eunotia minor (Kützing) Grunow & & & & + & & + & & + & & \\
\hline Eunotia cf. minor (Kützing) Grunow & & & + & & & & & & + & \\
\hline Eunotia sp. & + & & & & & & & & & \\
\hline Fragilaria bicapitata Mayer & + & & + & & & + & & & & \\
\hline Fragilaria biceps (Kützing) Lange-Bertalot & & + & & + & & & & + & & \\
\hline Fragilaria construens (Ehrenberg) Grunow f. construens & & & + & & + & & & & + & \\
\hline Fragilaria construens $\mathrm{f}$. venter (Ehrenberg) Hustedt & & + & & + & + & + & + & + & + & \\
\hline Fragilaria exiguiformis Lange-Bertalot & & & & & & + & & & & \\
\hline Fragilaria pinnata Ehrenberg & & + & & & + & & & + & & \\
\hline Fragilaria tenera (W. Smith) Lange-Bertalot & & & & & & & + & & & $\mathrm{V}$ \\
\hline Fragilaria sp. & & & & & & & & & + & \\
\hline Hantzschia abundans Lange-Bertalot & & & & & & & + & & + & \\
\hline Hantzschia amphioxys (Ehrenberg) Grunow & + & + & + & + & + & + & + & + & + & \\
\hline Hantzschia calcifuga Reichardt \& Lange-Bertalot & & & & & + & & + & & & \\
\hline Luticola acidoclinata Lange-Bertalot & & & & + & & + & + & & + & $\mathrm{R}$ \\
\hline Luticola goeppertiana (Bleisch) D.G. Mann & & & + & & + & & + & + & & \\
\hline Luticola mutica (Kützing) D.G. Mann & + & + & + & + & + & + & + & + & + & \\
\hline Luticola nivalis (Ehrenberg) D.G. Mann & + & + & + & + & + & + & + & + & + & \\
\hline Luticola paramutica (Bock) D.G. Mann & & & + & + & + & + & + & & + & \\
\hline Luticola ventricosa (Kützing) D.G. Mann & + & & + & & & & & & & \\
\hline Luticola sp. & + & & & & & & & & & \\
\hline Navicula gregaria Donkin & & & & + & & & & & & \\
\hline Navicula lanceolata (Agardh) Ehrenberg & + & & & & & & & + & & \\
\hline Navicula cf. reichardtiana Lange-Bertalot & + & + & & & & & & + & & \\
\hline Navicula sp. & & & & & & & & & + & \\
\hline Nitzschia abbreviata Lange-Bertalot \& Rumrich & & + & & & & & & & & \\
\hline Nitzscha palea (Kützing) W. Smith & & & & & & & & & + & \\
\hline Nitzschia sp. & & & & & & & + & & & \\
\hline Pinnularia borealis Ehrenberg var. borealis & + & + & + & + & + & + & + & + & + & \\
\hline Pinnularia schoenfelderi Krammer & & & & + & & + & & & & $\mathrm{E}$ \\
\hline Pinnularia subrupestris Krammer & & & & & & + & & & + & $\mathrm{E}$ \\
\hline Pinnularia viridiformis Krammer & & & & & & & & + & & $\mathrm{E}$ \\
\hline Planothidium frequentissimum (Lange-Bertalot) Lange-Bertalot & + & & & & & & & & & \\
\hline Planothidium lanceolatum (Brébisson) Lange-Bertalot & & & + & & & & & & & \\
\hline Stauroneis borrichii (Petersen) Lund & + & + & + & + & + & + & + & + & + & \\
\hline Stauroneis obtusa Lagerstedt & & & & & & & & & + & \\
\hline Stauroneis reichardtii Lange-Bertalot & & & + & & + & + & & + & + & \\
\hline Stauroneis termicola Lange-Bertalot \& Alles & + & + & + & + & + & & + & & + & $\mathrm{R}$ \\
\hline Thalassiosira cf. pseudonana Hasle \& Heimdal & & & & & + & & + & & + & \\
\hline Total taxa in a given month & 14 & 14 & 16 & 21 & 19 & 20 & 17 & 21 & 23 & \\
\hline Shannon-Wiener $\left(H^{\prime}\right)$ species diversity index & 1.60 & 1.78 & 2.09 & 1.94 & 2.49 & 2.38 & 2.37 & 1.87 & 1.97 & \\
\hline
\end{tabular}



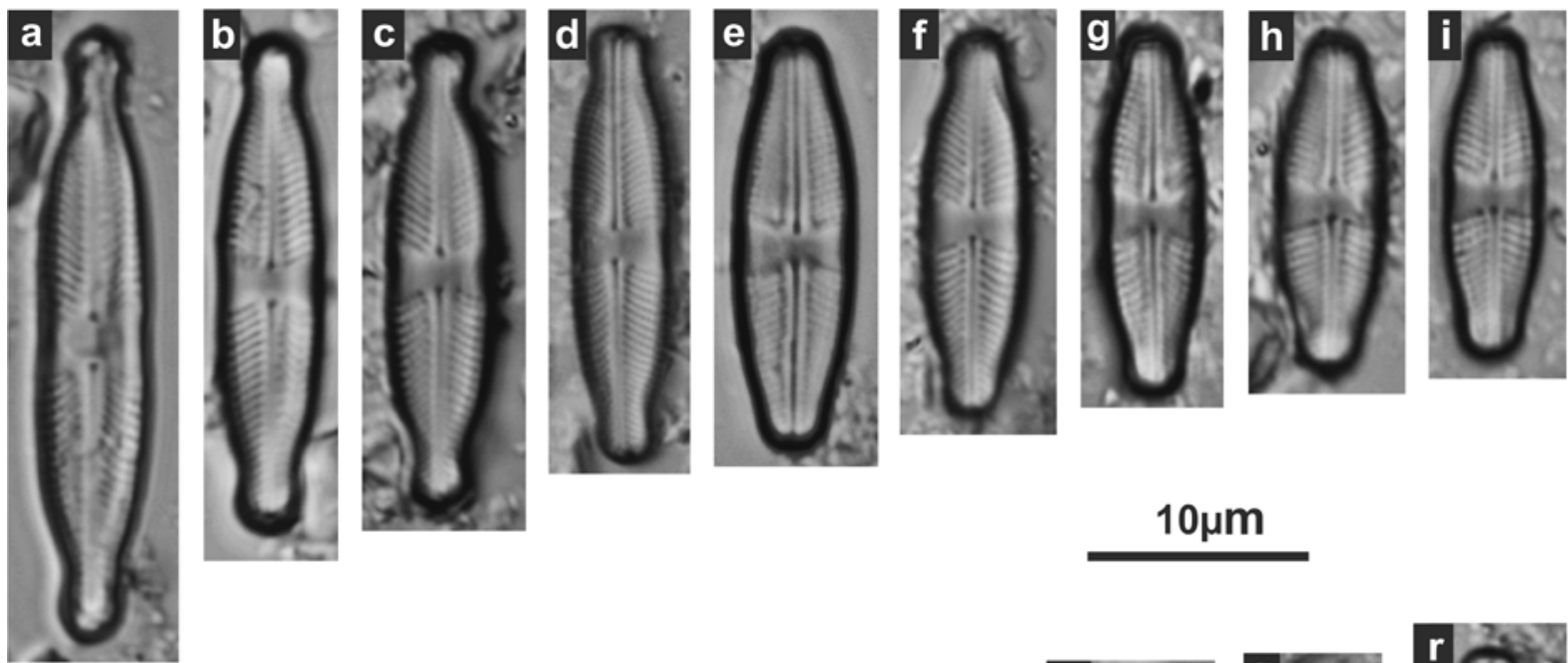

\section{$10 \mu \mathrm{m}$}
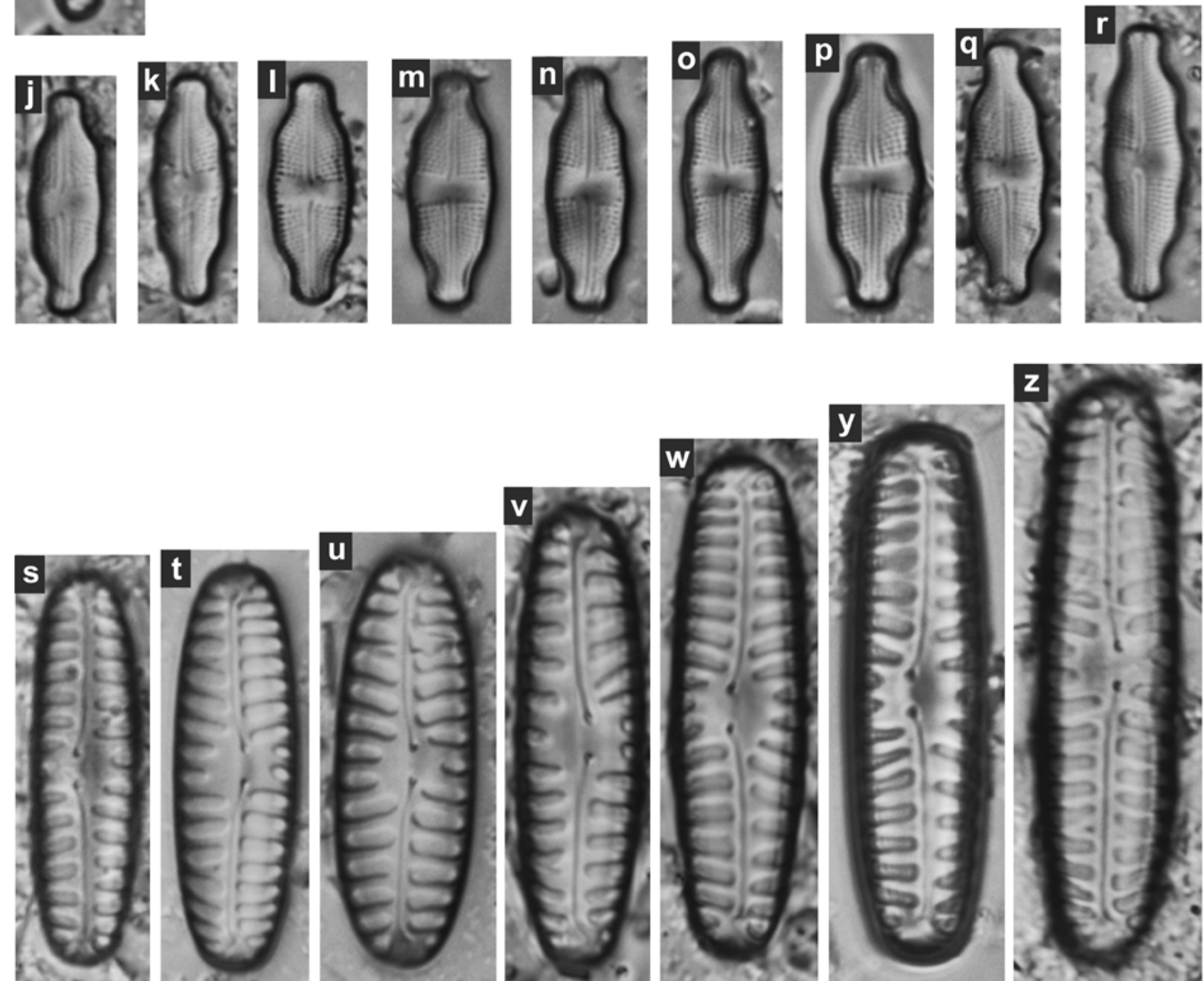

Fig. 3 Selected diatom taxa: Stauroneis borrichii (J.B. Petersen) J.W.G. Lund (a-i), Luticola nivalis (Ehrenberg) D.G. Mann (j-r), Pinnularia borealis var. borealis (Ehrenberg) Rabenhorst (s-z).

cultivated soil in northeastern Italy, Zancan et al. identified only 10 diatom species at four sites studied [13].

The study conducted on fallow soil in Pogórska Wola showed that in all the months of the study the most numerous taxa were Pinnularia borealis var. borealis and Hantzchia amphioxys, which are typical soil diatoms [18,32,36,37].

Pinnularia borealis var. borealis is probably a cosmopolitan species, frequent in aerial habitats, such as rocks, walls, soil and mosses $[18,36]$. It was also often found on cultivated soils in Boguchwała and Dąbrowa in the Podkarpacie region, but it was not the dominant taxa $[27,28]$.

Hantzchia amphioxys is a cosmopolitan species, one of the most frequent diatoms growing in dry places and on the soil $[18,32,37]$. Studies on soil algae concern mainly green algae and cyanobacteria, while diatoms are rarely found in the soil and among them H. amphioxys is the most frequently mentioned $[12,14,15,43,44]$. Hantzchia amphioxys is defined as a ubiquitous species, with a very wide geographical 

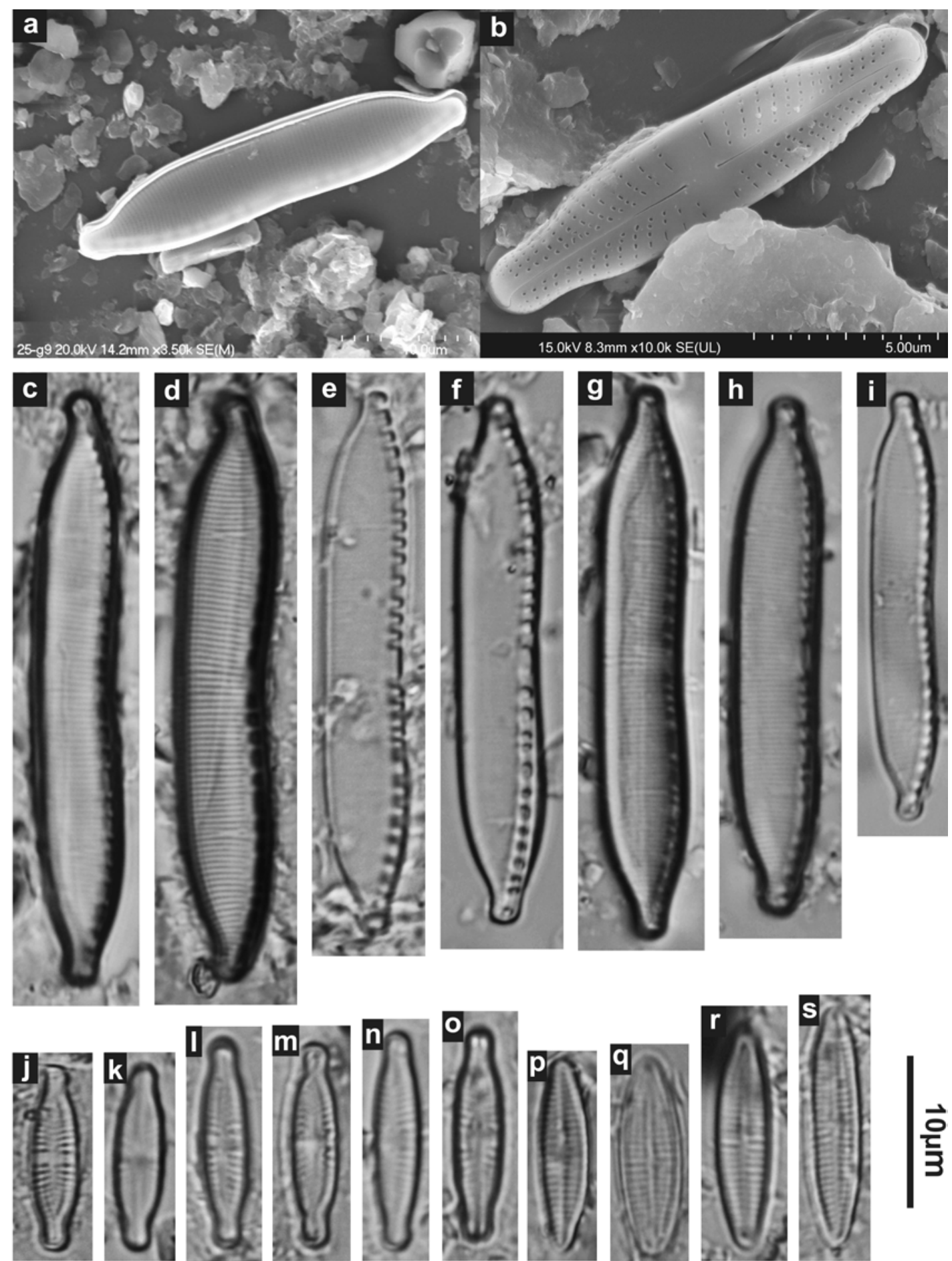

Fig. 4 Selected diatom taxa: Hantzschia amphioxys (Ehrenberg) Grunow (a,c-i), Stauroneis thermicola (J.B. Petersen) J.W.G. Lund (b,j-o), Achnanthidium pyrenaicum (Hustedt) Kobayasi (p-s).

range, which creates dwarf forms in dry habitats [45,46]. This species has also been noted on agricultural soils in the Podkarpackie Province, but did not exceed 5\% in the assemblage $[27,28]$.

The other two dominant species - Stauroneis borrichii and Luticola nivalis - occurred less frequently, constituting $5-20 \%$ of the assemblage. Both species are cosmopolitan and aerophitic $[18,32]$.

According to van Dam et al. [39], Stauroneis borrichii is a neutrophilous, oligosaprobous, fresh water species. Its first record in Poland comes from the Kobylanka stream, where it occurred rarely, mainly in samples with Vaucheria sp. [47,48]. However, Stanek-Tarkowska et al. [49] considered these algae to be a typical soil species, similar to H. amphioxys and $P$. borealis var. borealis.

The ecological preferences of the found diatom taxa for $\mathrm{pH}$, nitrogen uptake metabolism and moisture were determined. It was noted that neutral species (a pH of about 7) dominated in all months (from April to December), reaching an over $90 \%$ share of the assemblage. In terms of nitrogen 
Tab. 3 The dominance structure of diatom communities on fallow soil in Pogórska Wola.

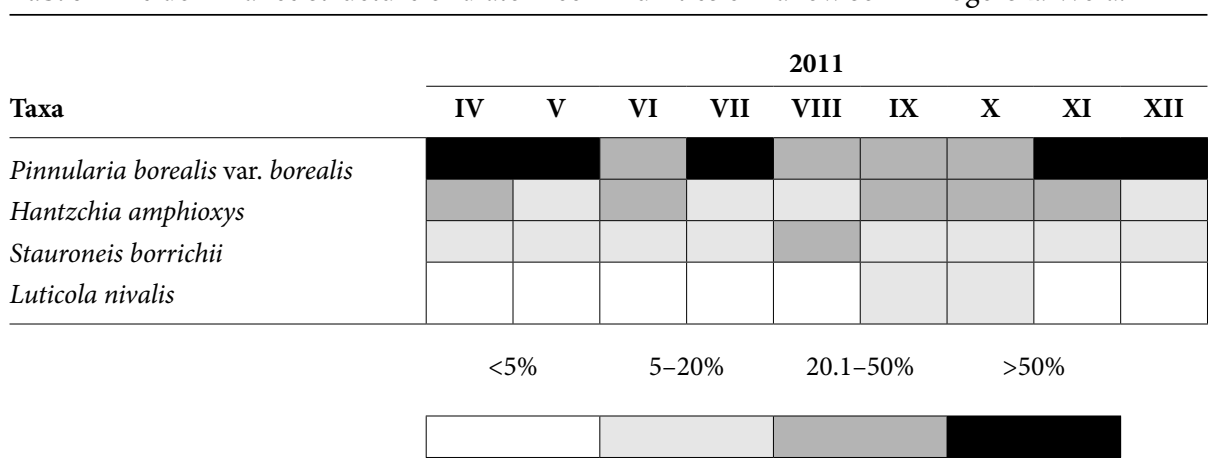

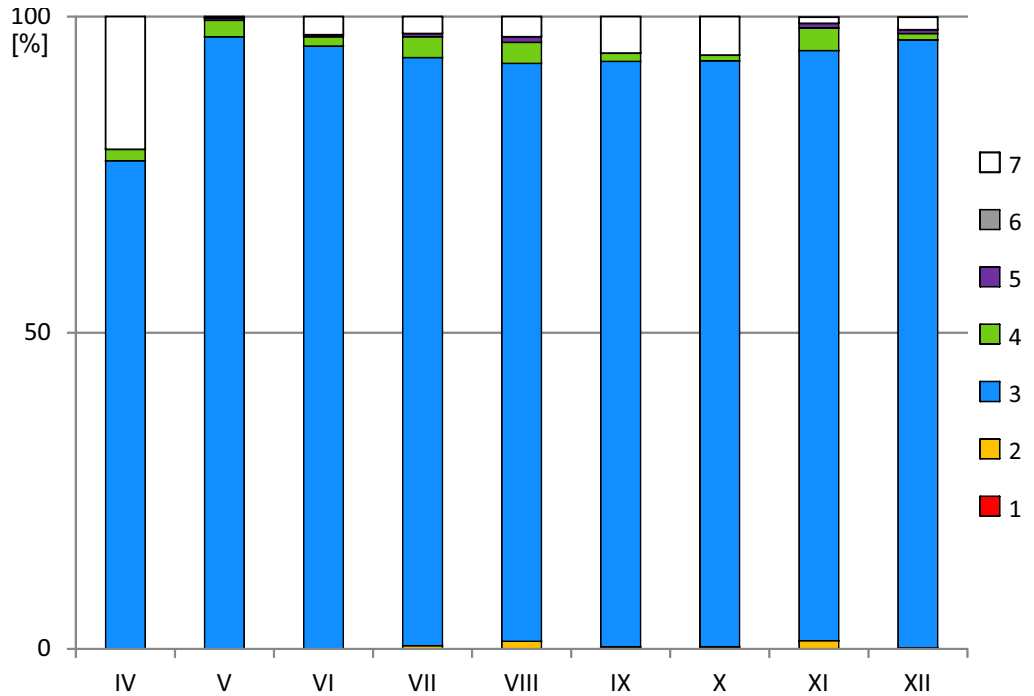

Fig. 5 Classification of ecological indicator values (according to van Dam et al. [39]). pH range: 1 - acidobiontic, 2 - acidophilous, 3 neutral, 4 - alkaliphilous, 5 - alkalibiontic, 6 - indifferent, no apparent optimum, 7 - unknown. IV-XII - months from April to December.

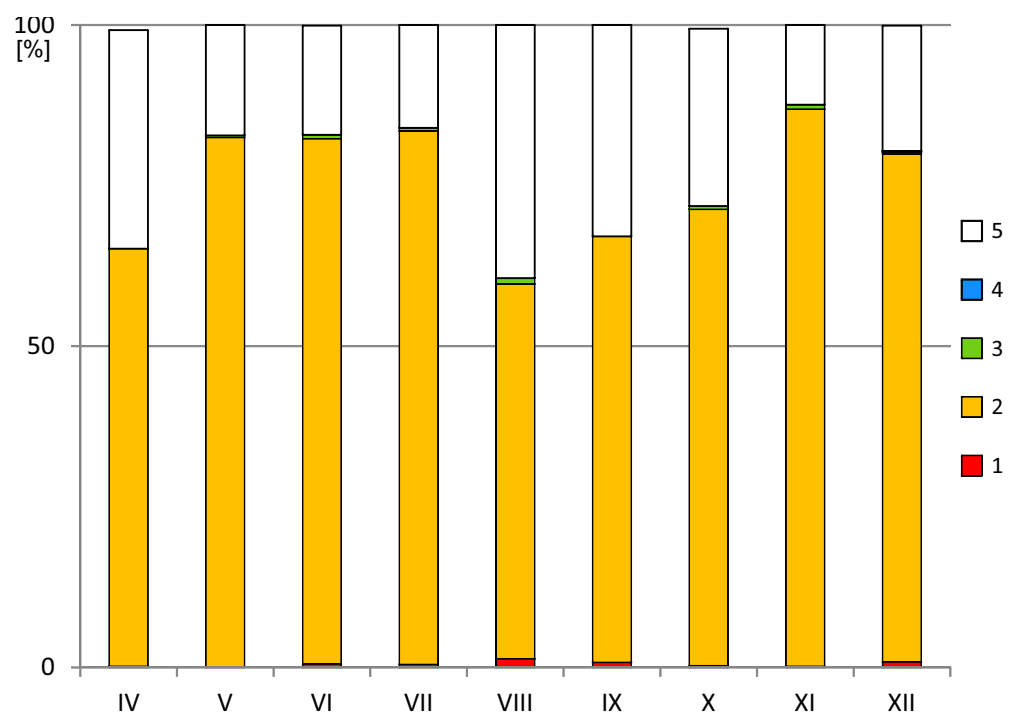

Fig. 6 Classification of ecological indicator values (according to van Dam et al. [39]). Nitrogen uptake metabolism type of diatom: 1 - nitrogen-autotrophic taxa, tolerating very small concentrations of organically bound nitrogen, 2 - nitrogen autotrophic taxa, tolerating elevated concentrations of organically bound nitrogen, 3 - facultatively nitrogen-heterotrophic taxa, needing periodically elevated concentrations of organically bound nitrogen, 4 - obligately nitrogen-heterotrophic taxa, needing continuously elevated concentrations of organically bound nitrogen unknown, 5 - unknown. IV-XII - months from April to December. 


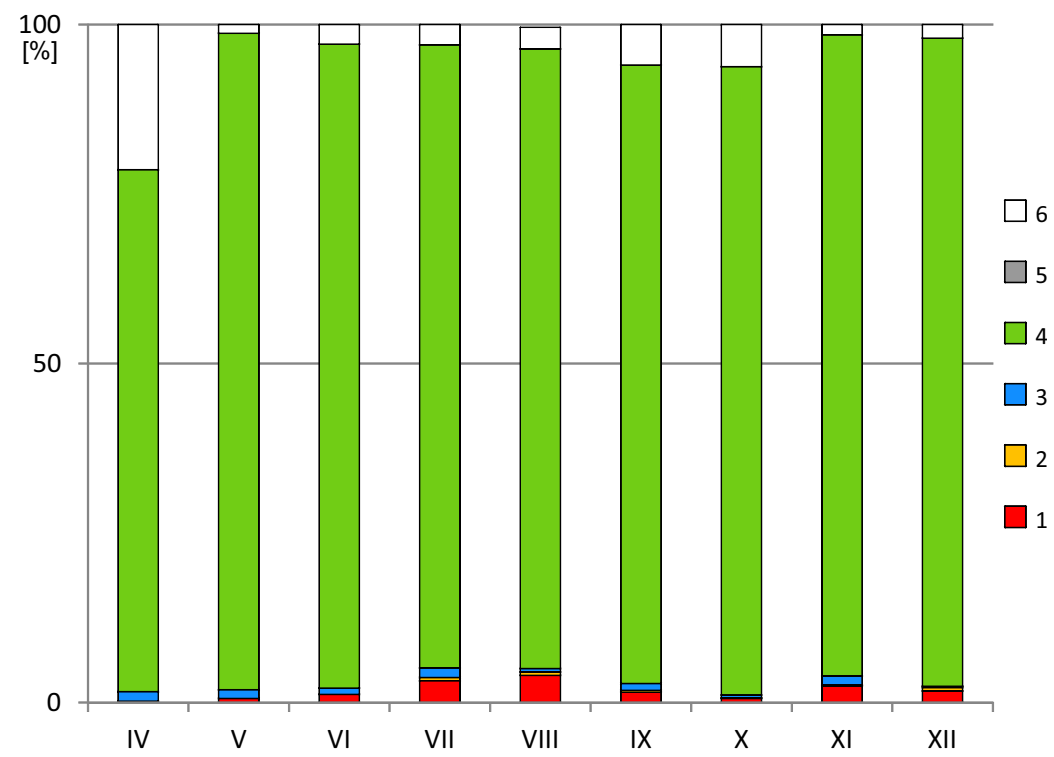

Fig. 7 Classification of ecological indicator values (according to van Dam et al. [39]). moisture: 1 - never or very rarely occurring outside water bodies, 2 - mainly occurring in water bodies, sometimes on wet places, 3 - mainly occurring in water, also rather regularly on wet and moist places, 4 - mainly occurring on wet and moist or temporarily dry places, 5 - nearly exclusively occurring outside water bodies, 6 - unknown. IV-XII - months from April to December.

content, nitrogen-autotrophic taxa, tolerating elevated concentrations of organically bound nitrogen, occurred most abundantly, as additionally indicated by the low content of nitrogen in the soil (Tab. 1). Diatoms growing mainly in wet, moist or temporarily dry places, primarily species of the genus Eunotia and Stauroneis [39], occurred in all the studied months. A slight increase in taxa from the groups that never or only very rarely occur outside water bodies was recorded in summer (VIII) and late autumn (XI-XII).

In addition to the cosmopolitan diatoms, which are common in different types of habitats, taxa from the Polish red list of algae [38] were also noted. Some of them, such as Pinnularia schoenfelderi and Stauroneis thermicola, occur very rarely in water habitats, as it seems that they find favorable growth conditions on soils.

Taxa from the genus Pinnularia, with the status of endangered species (category E) - P. schoenfelderi, P. subrupestris and $P$. viridiformis - are species occurring in European freshwaters from oligo- to dystrophic, with low to moderate electrolyte content [36,37]. In the area of Podkarpacie region, they were found in many rivers and streams, always as individual specimens, while they did not occur on cultivated soils [50]. Pinnularia schoenfelderi is probably a cosmopolitan species, often found in the sub-mountainous

\section{Acknowledgments}

Research were funded by Department of Soil Studies, Environmental Chemistry and Hydrology, Faculty of Biology and Agriculture, University of Rzeszów. The authors would like to acknowledge the Reviewers and Editors for valuable comments and suggestions..

\section{Authors' contributions}

The following declarations about authors' contributions to the research have been made: concept of the study: JST, TN; field work: JST, EK; writing and statistical analysis: JST, TN, NK, ŁP, AP. and mountainous regions of Europe [36] and occurring in waters with a neutral $\mathrm{pH}$, i.e. in springs of central Poland [51]. In the Podkarpacie Province, it is very rarely found in aquatic ecosystems [50], whereas the study conducted on soils near Tarnów showed that it grows better in a soil habitat.

According to Ettl and Gärtner [18], Stauroneis thermicola grows among wet mosses isolated on soils (England, Germany, the Czech Republic, Slovakia, Iceland, Denmark). According to van Dam et al. [39], it is an aerophilous and fresh brackish water species. In Poland it is a very rare species [52], regarded as rare (R) on the Polish red list of algae [38]. It was reported from a peat bog in Kraków [53], in the Raba River [54], central Poland [55], the Szczecin Lagoon [56], and the Kobylanka stream $[47,48]$. The study conducted on cultivated soils in the Podkarpacie region revealed that it best grows in soil habitats where it often reaches more than $20 \%$ in the total numbers and is a dominant species $[27,28,49]$.

The studied soil was characterized by high diatom species richness, mainly cosmopolitan species and typical for soil habitats. As a result of our study, we could not identify the factors that have a direct effect on the variation in diatom assemblages. The occurrence of soil diatoms may be associated with many habitat factors, so further studies are needed to better understand these relationships.

\section{Competing interests}

No competing interests have been declared.

\section{References}

1. Metting B, The systematics and ecology of soil algae. Bot Rev. 1981;47:195-312. http://dx.doi.org/10.1007/BF02868854

2. Gumiński S. Fizjologia glonów i sinic. Wrocław: Wydawnictwo Uniwersytetu Wrocławskiego; 1990. 
3. Johansen JR, Schubert LE. Algae in soil. Nova Hedwig. 2001;123:297-306

4. Booth WE. The thermal heath point of certain soil inhabiting algae. Proc Montana Acad Sci. 1946;5-6: 21-23.

5. Claus G. Beiträge zur Kenntnis der Algenflora der Abaltigeter Höhle. Hydrobiologia. 1962;19:192-222. http://dx.doi.org/10.1007/ BF00146362

6. Cameron RE, Blank GR. Desert algae: Soil crusts and diaphamous substrata as algal habitats. NASA Tech Rep. 1966;32-971:1-45.

7. Clair LL, Rushforth SR, Allen JV. Diatoms of Oregon Caves National Monument, Oregon. West N Am Nat. 1981;41:317-322.

8. Evans RD, Johansen JR, Microbiotic crusts and ecosystem processes. Crit Rev Plant Sci. 1999;18:183-225. http://dx.doi.org/10.1016/ S0735-2689(99)00384-6

9. Bogaczewicz-Adamczak B. Paleolimnologia jezior Borów Tucholskich w świetle badań kopalnych okrzemek. Zesz Nauk Uniw Gdańsk. 1990;150:1-133.

10. Hahn A, Neuhaus W. Boden-Diatomeen einer landwirtschaftlichen Nutzfläche bei Potsdam, Deutschland. Nova Hedwig. 1997;65:285-298.

11. Hoffmann L. Algae of terrestrial habitats. Bot Rev. 1989;55:77-105. http://dx.doi.org/10.1007/BF02858529

12. Sieminiak D. Glony glebowe - organizmy sprzyjające dobremu gospodarowaniu. Działalność Naukowa PAN. 2000;10:125-128.

13. Zancan S, Trevisan R, Paoletti MG. Soil algae composition under different agro-ecosystems in north-eastern Italy. Agric Ecosyst Environ. 2006;112:1-12. http://dx.doi.org/10.1016/j.agee.2005.06.018

14. Skalna E. Glony ziemne występujące w uprawach niektórych warzyw w Prusach koło Krakowa. Fragm Flor Geobot. 1979;25(4):607-648.

15. Żurek L. The influence of the herbicides LENACIL and PYRAZON on the soil algae, Ekol Pol. 1981;29(3):327-342.

16. Sieminiak D. Filamentous green alga Pleurastum sarcinoideum Groover et Bold - first record in Poland. Oceanol Hydrobiol Stud. 2007;36(1):249-254.

17. Sieminiak D. Unicellular green alga Scotiellopsis terrestris (Reisgl) Punčoch. and Kalina - first record in Poland. Oceanol Hydrobiol. Stud. 2009;38(2):163-169.

18. Ettl H, Gärtner G. Sylabus der Boden-, Luft- und Flechtenalgen. Stuttgart: Gustaw Fischer Verlag; 1995.

19. Skowroński T, Kalinowska R, Pawlik-Skowrońska B. Glony środowisk zanieczyszczonych metalami ciężkimi. Kosmos 2002;51(2):165-173.

20. Kalinowska R, Trzcińska M, Pawlik-Skowrońska B. Glony glebowe terenów pogórniczych skażonych metalami ciężkimi. Wiad Bot. 2008;52(3-4):63-79.

21. Bérard A, Rimet F, Capowiez Y, Leboulanger C. Procedures for determining the pesticide sensitivity of indigenous soil algae: a possible bioindicator of soil contamination? Arch Environ Contam Toxicol. 2004;46:24-31. http://dx.doi.org/10.1007/s00244-003-2147-1

22. Al-fredan MA, Fathi AA. Preliminary survey of edaphic algae in AlHasa Region, Saudi Arabia. Pak J Biol Sci. 2007;10(18):3210-3214. http://dx.doi.org/10.3923/pjbs.2007.3210.3214

23. Dorokhova MF. Diatoms as indicators of soil conditions in oil production regions. Oceanol Hydrobiol Stud. 2007;36(1):129-135.

24. Kalinowska R, Pawlik-Skowrońska B. Metal resistance of soil algae (Chlorophyta) occurring in post-flotation $\mathrm{Zn} / \mathrm{Pb}$ - and $\mathrm{Cu}$-tailing ponds. Pol J Ecol. 2008;56(3):415-430.

25. Škaloud P. Species composition and diversity of aero-terrestial algae and Cyanobacteria of the Boreč Hill ventaroles. Fottea. 2009;9(1):65-80

26. Heger TJ, Straub F, Mitchell EAD. Impact of farming practices on soil diatoms and testate amoebae: A pilot study in the DOK-trial at Therwil, Switzerland. Eur J Soil Biol. 2012;49:31-36. http://dx.doi. org/10.1016/j.ejsobi.2011.08.007

27. Stanek-Tarkowska J, Noga T. Zbiorowiska okrzemek rozwijające się na glebach pyłowych pod uprawą kukurydzy w rejonie Podkarpacia. Fragm Flor Geobot Pol. 2012;19(2):525-536.

28. Stanek-Tarkowska J, Noga T. Diversity of diatoms (Bacillariophyceae) in the soil under traditional tillage and reduced tillage. Inżynieria Ekologiczna. 2012;30:287-296

29. Kondracki J. Geografia regionalna Polski. Warszawa: Wydawnictwo Naukowe PWN; 2001

30. Pulit F. Opracowanie ekofizjograficzne dla gminy Skrzyszów. Tarnów; 2003.

31. Kawecka B. Diatom diversity in streams of the Tatra National Park (Poland) as indicator of environmental conditions. Kraków: Szafer Institute of Botany, Polish Academy of Sciences; 2012.

32. Krammer K, Lange-Bertalot H. Bacillariophyceae. 1. Naviculaceae. In: Ettl H, Gerloff J, Heyning H, Mollenhauer D, editors. Süsswasserflora von Mitteleuropa 2(1). Stuttgart: G. Fischer Verlag; 1986. p. 1-876.

33. Krammer K, Lange-Bertalot H. Bacillariophyceae. 2. Bacillariaceae, Epithemiaceae, Surirellaceae. In: Ettl H, Gerloff J, Heyning H, Mollenhauer D, editors. Süsswasserflora von Mitteleuropa 2(2). Stuttgart: G. Fischer Verlag; 1988. p. 1-596.

34. Krammer K, Lange-Bertalot H. Bacillariophyceae. 3. Centrales, Fragilariaceae, Eunotiaceae. In: Ettl H, Gerloff J, Heyning H, Mollenhauer D, editors. Süsswasserflora von Mitteleuropa 2(3). Stuttgart: G. Fischer Verlag; 1991. p. 1-576.

35. Krammer K, Lange-Bertalot H. Bacillariophyceae. 4. Achnanthaceae, Kritische Ergänzungen zu Navicula (Lineolate) und Gomphonema Gesamtliteraturverzeichnis. In: Ettl H, Gerloff J, Heyning H, Mollenhauer D, editors. Süsswasserflora von Mitteleuropa 2(4). Stuttgart: G. Fischer Verlag; 1991. p. 1-437.

36. Krammer K. The genus Pinnularia. In: Lange-Bertalot H, editor. Diatoms of Europe 1. Vaduz: A.R.G. Ganter Verlag K.G.; 2000. p. 1-703.

37. Hofmann G, Werum M, Lange-Bertalot H. Diatomeen im SüsswasserBenthos von Mitteleuropa. Bestimmungsflora Kieselalgen für die ökologische Praxis. Über 700 der häufigsten Arten und ihre Ökologie. In: Lange-Bertalot H, editor. Königstein: A.R.G. Ganter Verlag K.G.; 2011. p. 1- 908 .

38. Siemińska J, Bąk M, Dziedzic J, Gąbka M, Gregorowicz P, Mrozińska T, et al. Red list of the algae in Poland. In: Mirek Z, Zarzycki K, Wojewoda W, Szeląg Z, editors. Red list of plants and fungi in Poland. Kraków: W. Szafer Institute of Botany, Polish Academy of Sciences; 2006. p. 37-52.

39. van Dam H, Martens A, Sinkeldam J. A coded checklist and ecological indicator values of freshwater diatoms from the Netherlands. Neth J Aquat Ecol. 1994;28(1):117-133. http://dx.doi.org/10.1007/ BF0233425

40. Tjurin IV. Organičeskoe veščestvo počvy i ego rol' v plodorodii. Moskva: Nauka; 1965.

41. Lityński T, Jurkowska H, Gorlach E. Analiza chemiczno-rolnicza. Warszawa: Wydawnictwo Naukowe PWN; 1976.

42. Czyż EA, Dexter AR, Dębowska H, Stanek-Tarkowska J. Wpływ uproszczonej uprawy konserwującej na kształtowanie właściwości fizycznych gleby pyłowej w regionie Podkarpacia. 2009; Zesz Probl Postępów Nauk Rol. 543:57-68.

43. Sieminiak D. Evaluation of algal biomass in the soil of a barren land. Ekol Pol. 1996;44(3-4):225-243.

44. Sieminiak D. Biomass of soil algae under rye in different crop rotation systems. Pol J Soil Sci. 1998;31(2):79-85.

45. Hayek JM, Hulbary RL. A survey of soil diatoms. Proc Iowa Acad. Sci. 1956;63:327-338.

46. Patrick R. Ecology of freshwater diatoms and diatom communities. In: Werner D, editor. The biology of diatoms. London: Blackwell Sci. Publ.; 1977. p. 284-332.

47. Wojtal A, Sobczyk Ł. Composition and structure of epilithic diatom assemblages on stones of different size in a small calcareous stream (S Poland). Algol Stud. 2006;119:105-124. http://dx.doi. org/10.1127/1864-1318/2006/0119-0105

48. Wojtal A. Diatom flora of the Kobylanka stream near Kraków 
(Wyżyna Krakowsko-Częstochowska Upland, S Poland). Pol Bot J. 2009;54(2):129-330.

49. Stanek-Tarkowska J, Noga T, Pajączek A, Peszek Ł. The occurrence of Sellaphora nana (Hust.) Lange-Bert. Cavacini, Tagliaventi and Alfinito, Stauroneis borrichii (J.B. Petersen) J.W.G. Lund, S. parathermicola Lange-Bert. and S. thermicola (J.B. Petersen) J.W.G. Lund on agricultural soils. Algol Stud. 2013;142:109-120. http://dx.doi. org/10.1127/1864-1318/2013/0114

50. Noga T, Stanek-Tarkowska J, Kocielska-Streb M, Kowalska S, Ligęzka $\mathrm{R}$, Kloc U, et al. Endangered and rare species of diatoms in running and standing waters on the territory of Rzeszów and the surrounding area. In: Kostecka J, Kaniuczak J, editors. Practical Applications of Environmental Research. Rzeszów; 2012. p. 331-340.

51. Żelazna-Wieczorek J. Diatom flora in springs of Łódź Hills (central Poland). Biodiversity, taxonomy and temporal changes of epipsammic diatom assemblages in springs affected by human impact. Diatom Monographs. 2011;13:1-420.

52. Siemińska J, Wołowski K. Catalogue of Polish prokaryotic and eucaryotic algae. Kraków: W. Szafer Intitute of Botany, Polish Academy of Sciences; 2003.

53. Rumek A. 1946. Okrzemki torfowiska w Borku Fałęckim koło Krakowa. Mat Fizjogr Kraju. 2:1-36.

54. Starmach K. Homeothrix crustacea Worochin and accompanying algae in the upper course of the river Raba. Acta Hydrobiol. 1966;8(3-4):309-320.

55. Rakowska B. Studium różnorodności okrzemek ekosystemów wodnych Polski niżowej. Łódź: Wydawnictwo Uniwersytetu Łódzkiego; 2001.

56. Bąk M, Witkowski A, Lange-Bertalot $H$. Diatom flora diversity in the strongly eutrophicated and $\beta$-mesosaprobic waters of the Szczecin Lagoon, NW Poland, Southern Baltic Sea. In: Ognjanova-Rumenova N, Manoylov K, editors. Advances in Phycological Studies, Festschrift in Honour of Prof. Dobrina Teminskova-Topalova. Sofia: Pensoft Publishers \& University Publishing House; 2006. p. 293-317.

\section{Różnorodność zbiorowisk okrzemek rozwijających się na odłogowanej glebie w Pogórskiej Woli koło Tarnowa}

\section{Streszczenie}

Glony glebowe przyczyniają się do wzbogacenia gleby w substancję organiczną poprzez wydzieliny pozakomórkowe, biorą udział w uwalnianiu składników pokarmowych do środowiska oraz wpływają na właściwości i stabilność gleb. Badania przeprowadzone w okresie od kwietnia do grudnia 2011 roku miały na celu poznanie bogactwa gatunkowego okrzemek rozwijających się na odłogowanej glebie w Pogórskiej Woli koło Tarnowa wytworzonej na piaskach luźnych oraz ocenę stanu ekologicznego gleby na podstawie wybranych właściwości fizyko-chemicznych i występujących w glebie zbiorowisk okrzemek. Gleba na badanym stanowisku w Pogórskiej Woli charakteryzowała się kwaśnym odczynem (pH: 4.1-5.3), najniższe wartości pH zanotowano w miesiącach letnich. Zawartość substancji organicznej wynosiła od $1.37 \%$ w listopadzie do $2.04 \%$ w maju 2011 roku. Podczas badań prowadzonych od kwietnia do grudnia 2011 roku oznaczono łącznie 57 taksonów okrzemek z 19 różnych rodzajów. Najwięcej taksonów stwierdzono w rodzajach: Fragilaria (8) i Luticola (7). Cztery taksony - Pinnularia borealis Ehrenberg var. borealis, Stauroneis borrichii (Petersen) Lund, Hantzschia amphioxys (Ehrenberg) Grunow i Luticola nivalis (Ehrenberg) D.G. Mann), których liczebność przynajmniej w jednym miesiącu wynosiła powyżej 5\% uznano za gatunki dominujące. Najliczniejsze populacje tworzyła Pinnularia borealis var. borealis osiągając w kwietniu i lipcu ponad $60 \%$ liczebności w zbiorowisku. Preferencje ekologiczne okrzemek przedstawiono w oparciu o listę van Dama i in. Zdecydowaną większość okrzemek (ponad 90\%) stanowily taksony obojętne (pH około 7). Pod względem zawartości azotu dominowały taksony tolerujące podwyższoną zawartość azotu związanego organicznie. Na wszystkich stanowiskach zdecydowanie przeważały okrzemki wystepujące głównie na wilgotnych lub tymczasowo wyschniętych miejscach. Stwierdzono występowanie siedmiu taksonów okrzemek z polskiej czerwonej listy glonów, z których trzy znalazły się w kategorii wymierające (E): P. schoenfelderi, P. subrupestris i $P$. viridiformis. 